\title{
OSOBA, ČLOVEK A (AKO) INDIVÍDUUM VO FILOZOFICKOM UČENÍ P. L. LAVROVA (KRITICKÉ POZNÁMKY K BYZANTSKEJ A SLOVANSKEJ DUCHOVNOSTI) ${ }^{1}$
}

\author{
Person, Man and (As an) Individual in Philosophical Teachings \\ of P. L. Lavrov (Critical Notes on Byzantine and Slavic spirituality)
}

\author{
Ondrej Marchevský
}

DOI: 10.17846/CL.2018.11.1.138-146

\begin{abstract}
MARCHEVSKÝ, Ondrej. Person, Man and (As an) Individual in Philosophical Teachings of Peter L. Lavrov (Critical Notes on Byzantine and Slavic Spirituality). The contribution is a result of author's interest in the legacy of Russian Narodism and, within its framework, the works of Petr Lavrovich Lavrov (1823 - 1900). The contribution analyses that part of Lavrov's extensive work which could be labelled as philosophy of history. The selected part of Lavrov's works are a result of his long-term interest and effort to interconnect philosophical reflections with the real needs of political practice in the Russian context of the second half of the 19th century. Lavrov's views can be seen as a critical reflection of values created by the Byzantine and Slavic spirituality. Faith is not accepted as faith in God. It is regarded as a strong belief which can lead to political action and social change. It is a belief in goals created by man. This represents the fundament for the creation of a better world. In that respect, one can identify Lavrov's distinctive reflections concerning the values and actions based on these values. Actions, based on certain values, and the process of realisation of shared or accepted value frameworks, represent, in Lavrov's understanding, the basis, or the starting point for a definition of man and (as an) individual, as an acting individual.
\end{abstract}

Keywords: person, man, individual, Russian narodism, P. L. Lavrov

Abstrakt: MARCHEVSKÝ, Ondrej. Osoba, človek a (ako) indivíduum vo filozofickom učení P. L. Lavrova. (Kritické poznámky k byzantskej a slovanskej duchovnosti). Príspevok je výsledkom záujmu o skúmanie ruského národníckeho myšlienkového dedičstva a v jeho rámci tvorby Petra Lavroviča Lavrova (1823 - 1900). Príspevok venuje pozornost tej časti bohatej tvorby Lavrova, ktorú by bolo možné nazvat filozofiou dejín. Uvedená oblast' tvorby Lavrova je výsledkom jeho dlhodobého záujmu, snahy o prepojenie filozofických úvah s potrebami reálnej politickej praxe v kontexte Ruska 2. polovice 19. storočia. Názory Lavrova je možné chápat ako kritickú reflexiu hodnôt vytvorených gréckou, byzantskou a slovanskou duchovnostou. Vieru neprijíma ako vieru v Boha. Chápe ju ako silné presvedčenie, ktoré môže viest’ $\mathrm{k}$ politickému konaniu a spoločenskej zmene. Je vierou v ciele, ktoré tvorí človek. Je východiskom odhodlania pre tvorbu lepšieho sveta. V rámci týchto snáh je možné identifikovat osobité uvažovanie Lavrova o hodnotách a konaní človeka na základe takýchto hodnôt. Konanie založené na hodnotách, proces realizácie zdielaných alebo prijímaných hodnotových

Predložený text je výstupom z riešenia projektu VEGA č. 1/0124/16 Ruská a slovenská filozofia osoby v lingvistických a filozofických súvislostiach. 
rámcov, tvorí pre Lavrova bázu, východisko pre vymedzenie človeka a (ako) indivídua, indivídua konajúceho.

Klúčové slová: osoba, človek, indivíduum, ruské národníctvo, P. L. Lavrov

Myslenie ruskej proveniencie 19. storočia býva oprávnene nazývané zlatým vekom. Je to obdobie plné nadčasových či nečasových myšlienok, posolstiev, ktorých význam rezonuje a bude rezonovat naprieč vzdelaným ludstvom všetkých pokolení. Je to zároveň doba, ktorá rodí udalosti vnímané ako vel'ké traumy ruských dejín, spomedzi ktorých je najcitlivejšou témou revolúcia roku 1917.

Spoločne s tvorbou V. S. Solovjova, F. M. Dostojovského, L. N. Tolstoja, A. P. Čechova sa rozvíja aj myslenie striktne sekulárne, ktorého cielom je zmena Ruska, zmena rázna a rýchla, revolučná. Je stelesnená tvorbou tzv. národníkov².

Práve jednej z klúčových postáv uvedeného hnutia je venovaná predkladaná práca. Peter Lavrovič Lavrov je významnou postavou, ktorá nie je príliš známa ani v domácom, ani v českom a slovenskom diskurze. V ruskom prostredí, podobne ako ostatní národníci je to intelektuálna persona non grata.

Nádejame sa, že predkladanou prácou prispejeme k obohateniu reflexie ruskej filozofie v slovenskom filozofickom výskume a konkrétne k osvete národníckej filozofie, ktorá je jej súčastou (Pružinec - Gallo 2016, 2).

V snahe predstavit Lavrovovu koncepciu človeka, resp. osoby a indivídua považujeme za potrebné zdôraznit', že táto otázka predstavuje čast', fragment jeho bohatého a pomerne kontroverzného tvorivého odkazu. Naša práca tak predstavuje nevyhnutnú a vedomú redukciu, ktorá nepretenduje na postihnutie celku jeho odkazu. Takýto zámer je jednoducho v poskytnutom formáte odbornej štúdie nerealizovatelný. Budeme sa ale snažit zakomponovat’ vybranú tematiku do kontextu tvorby Lavrova a jej hlavných intencií. V súlade s týmto zámerom si dovolíme stručne, vskutku v podobe črty predstavit postavu Petra L. Lavrova. Zároveň uvedieme textové východiská pri skúmaní uvedeného problému, teda práce zásadné z pohladu zvolenej problematiky človeka, osoby a indivídua.

Ak by sme si chceli priblížit život P. L. Lavrova ${ }^{3}$, mali by sme hovorit o horlivom diskutérovi a publicistovi 2. pol. 19. storočia, ktorý bol profesionálne vojakom-delostrelcom a zároveň profesorom vyššej matematiky na Peterburskom delostreleckom učilišti. Bol veteránom Krymskej vojny. Za zmienku stojí jeho snaha propagovat' spoločenskú užitočnost̉ filozofie. V roku 1860 realizoval intelektuálne podujatie s názvom Tri besedy o súčasnom význame filozofie, ktorý je v ruskom prostredí úplne prvým pokusom predstavit filozofiu ako niečo spoločensky užitočné. Ako niečo, čo môže mat pozitívny vplyv na vývoj spoločenského diania.

Práve vplyvu na spoločenské dianie, ktoré by dokázalo zmenit dobové Rusko bola venovaná hlavná pozornost' Lavrova. Tomu zodpovedá jeho spoločenská angažovanost’ aj písaná tvorba, z ktorej sú pre zvolenú tému určujúce práce: Historické listy (Istoričeskije pisma) ${ }^{4}$, Sociálna revolúcia a úlohy morálky (Socialnaja revolucija i zadači nravstvennosti) ${ }^{5}$, Staré otázky (Starye voprosy).

Snaha Lavrova vplývat na spoločenské dianie je vyjadrená pohybom jeho úvah medzi dvoma rámcami, ktoré sú zastúpené symbolmi kabinetu a ulice. V svojej dobe vníma poznatky nadobudnuté ludským myslením ako úplne odtrhnuté od spoločenského diania, od potrieb ludí. Kabinetná

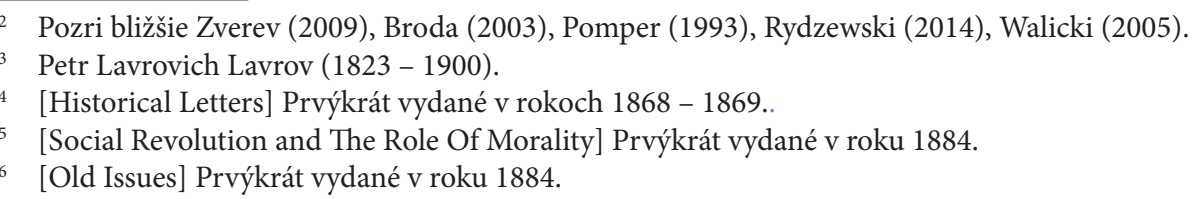


múdrost je predmetom posmechu tých, ktorí žijú na ulici. Lavrov sa svojou tvorbou snaží o prepojenie týchto dvoch prostredí, čo je badatel’né aj z nasledovného: „My formulujeme len otázky, no čitatel, ku ktorému sa obraciame, čitatel', ktorý neodsúdil predchádzajúce strany ako snahu pobúrit jeho myslenie, rutinu jeho života, čitatel', ktorý sa zamyslel nad úlohami formulovanými na týchto stránkach, sám nájde odpovede na dané parciálne otázky. Tieto odpovede netreba čítat z knihy, verit’ v ne, je ich potrebné čerpat' zo života, musia vytvorit základy životného presvedčenia" (Lavrov 2010a, 289). Čitatel’om je človek jeho doby. Považujeme za dôležité spomenút, že $\mathrm{v}$ intenciách jeho tvorby je možné používat pojmy osoba a človek ako synonymá, no pojem indivíduum $\mathrm{z}$ tohto rámca vystupuje. Je nositelom iného obsahu ako spomínané dva pojmy. Osoba, resp. človek predstavuje neuralgický bod a zároveň Achillovu pätu možných zmien v spoločnosti. Problematiku osoby, resp. človeka a indivídua je tak možné badat ako špecifický problém na ceste prepojenia kabinetu a ulice. Náš redukovaný prístup tak spočíva v priblížení jedného - zásadného - faktoru v procese týchto plánovaných ráznych spoločenských zmien. Ten však nie je jediný. Mohli by sme spomenút jeho úvahy o podmienenosti vedeckých skúmaní či tiež jeho konceptualizáciu progresu, ktoré predstavujú dalšie aspekty jeho úvah medzi kabinetom a ulicou.

Ak sa Lavrov obracia na človeka, tak sa naň obracia ako na bytost', ktorá ako jediná svojimi percepčnými schopnostami dokáže vnímat písané slovo, hĺbku myšlienok. Je tiež jedinou bytostou, ktorá poznatky o spoločnosti dokáže pretavit do konkrétnych činov, na reálnu spoločenskú prax. Potrebu tohto aktu zdôrazňuje nasledovne: „Filozofické idey nie sú dôležité ako prejavy procesu rozvoja ducha v jeho logickej abstrakcii, ale slúžia človeku ako logické formy uvedomenia si vyššej alebo nižšej dôstojnosti, širšie alebo užšie koncipovaných cielov jeho existencie, sú dôležité ako formy vzdoru proti prežívanej skutočnosti v mene túžby po lepšom a spravodlivejšom spoločenskom zriadení alebo ako formy uspokojenia sa s existujúcim zriadením“ (Lavrov 2010a, 52). Oproti prvej myšlienke rámcujúcej zámer Lavrova tu možno badat posun. Lavrov už nie je len tým, kto otvára otázky, naznačuje smerovanie. Idey majú viest’ k vzdoru, ku zmene.

Ak sme naznačili, že medzi človekom, resp. osobou a indivíduom je významový posun, preto považujeme za vhodné pozriet’ sa na povahu tejto diferenciácie. Pohlad na povahu človeka, osoby a indivídua bude tvorit jadro nami predloženej práce.

Úvahy o človeku, osobe a indivíduu majú u Lavrova spoločné to, že sa nepohybujú na nijakej metafyzickej úrovni. Lavrov nesleduje zámer postihnút človeka či indivíduum v jeho samotnej najvlastnejšej podstate. Nazerá na človeka, osobu a indivíduum v plnom súlade so svojim zámerom zmenit spoločnost’ a Rusko. Ide o niečo, čo by sme mohli nazvat funkčným pohladom. Je to pohlad, ktorý určuje miesto človeka v spoločenskom svete. Nazerá na to, čo z ludských daností, vrodených, naučených či tradičných určuje jeho pohlad na svet, život v spoločnosti, jeho rozhodovanie a konanie.

Človeka, osobu vníma ako bytost', ktorá disponuje možnostou stat’ sa „plne kriticky mysliacim indivíduom“ (Lavrov 2010a, 131). Nie je to ale jediná vyčerpávajúca charakteristika. Na inom mieste uvádza: „Morálne rozumná činnosț je len jedným z druhov ludskej činnosti, mimo nej človek môže konat automaticky výlučne pod vplyvom zvieracích pudov, rutiny alebo vášní. Je možné dúfat, že progres ludstva zníži podiel činností, ktoré vychádzajú z týchto vplyvov, no zatial’ sú stále prítomné“ (Lavrov 2010a, 209). Poukazuje tak aj na pudové sklony a morálny element v človeku.

Osobité postavenie medzi pudovými, či možno povedał živočíšnymi sklonmi ${ }^{7}$ má jedna z nich: „Medzi mnohými výlučne živočíšnymi pôžitkami nachádzame pôžitok ${ }^{8}$ súcitu, pričom

V zmysle prirodzene vlastných človeku ako súčasti prírody. Nie je to chápané ako nejaká výchovou získaná alebo naučená vlastnost', ale ako niečo vlastné človeku ako takému. Lavrov to ale nijak bližšie nerozpracúva.

8 Rus. naslaždenije - pôžitok, rozkoš. Dovolíme si tvrdit, že ide o nesmierne zaujímavé a podnetné slovné 
smerovanie $\mathrm{k}$ nemu predstavuje prvotné ohraničenie boja všetkých proti všetkým. Nech sa už súcit prejavuje v akejkolvek forme, zmierňuje napätie medzi osobami alebo ich dokonca potiera“ (Lavrov 2010b, 356).

Lavrov poukazuje aj na spoločenskú stránku alebo spoločenskú prirodzenost’ človeka: „Človek ako izolovaná bytosṫ neexistuje. Je spoločenským tvorom a mimo spoločnosti sa nemôže stat' tým, čím je“ (Lavrov 2010b, 355). Dané tvrdenie by sme mohli považovat za nevyhnutný predpoklad, ak berieme na vedomie základný ciel', o ktorý sa Lavrov vo svojej tvorivej činnosti snaží.

Lavrov poukazuje ešte na jednu dôležitú vlastnosť človeka, ktorú nazýva ako vedomý sebaklam. Človeku je vlastné, že sám seba klame. Robí tak dokonca aj vtedy, ked’ tvrdí, že nechce byt' klamaný a nechce byṫ otrokom klamu či nejakej fikcie: „Človek ako čast̉ sveta a otrok prírody si nikdy nechcel uvedomit’ svoje otroctvo. Človek, ktorý sa neustále podriaduje nezmyselným náklonnostiam a náhodným podmienkam, nechcel nikdy nazvat svoje náklonnosti priamo nezmyselnými a zdroje svojho konania hladat v náhode. $\mathrm{V}$ tých najintímnejších hlbinách jeho duše nachádzame snahu utajit pred sebou svoju závislost' na zákonoch podvedomia, niečím pred sebou zakryt svoju vrtkavost' a nedôslednost' v konani' (Lavrov 2010a, 161). ${ }^{9}$

Špecifickým druhom alebo nástrojom sebaklamu je idealizácia. Nachádzame si neustále ospravedlnenia svojich činov - tak hlúpych, zlých, ako aj tých rozumných a dobrých. Lavrov to považuje za nevyhnutnú súčast’ našej spoločenskej existencie, totiž do rámcov idealizácie zapadá tvorba našich cielov, hodnotových východísk, ktoré určujú naše správanie a konanie. Táto idealizácia nemusí existovat len na úrovni jednotlivca, ale aj na spoločenskej úrovni, úrovni štátnej a v širších súvislostiach spoločenského života. Tvorí princípy, podla ktorých sa správame, správanie hodnotíme, na základe čoho vychovávame a vzdelávame. U Lavrova by sme mohli vidiet', že idealizácia môže mat podobu funkčnú a deštruktívnu. Príkladom funkčnej je jeho koncepcia progresu zastúpená $\mathrm{v}$ ucelenej podobe ideálom progresu. Teda ideálom, ktorý by podla Lavrova mal byt’ naplňnaný v mene všeobecného blaha ruského ludu. Aj ked'sme uviedli, že ide o samostatný rámec úvah Lavrova, dovolíme si naznačit jeho vnímanie tohto ideálu v hutnej podobe: „Rozvoj indivídua vo fyzickej, racionálnej a morálnej rovine, ustanovenie pravdy a spravodlivosti v spoločenských formách - to je krátka formula, zahrňujúca, ako sa domnievam, všetko, čo je možno považovat za progres“ $(2010 \mathrm{a}, 81)$. Robíme tak preto, aby sme vytvorili pre čitatela aspoň rámcový náčrt toho, ako obsah i funkciu ideálu Lavrov uchopuje. Považujeme za potrebné zdôraznit, že takýchto koncepcií a dobových vymedzení by mohlo byt' viacero. Lavrov sa snaží zastávat’ názor, že spoločnost’ si má sama určit, aký presný ideál bude sledovat a snažit sa napĺňat. Zásadné je to, že tento ideál nemá byt’ spoločnosti naoktrojovaný akousi vyššou mocou, ktorá sa v jeho chápaní väčšinou opiera len o tradíciu.

Ak by sme chceli oddelit funkčnú idealizáciu od tej deštrukčnej, tak by sme mohli uviest', že základný rozdiel spočíva $\mathrm{v}$ absolutizácii parciálnych ciel’ov. V momente, ked’ sa parciálny ciel pod akousi hrozbou ponúka ako jediný prijatel'ný, stáva sa ohrozením pre spoločnost'. To isté platí v momente, ked' sa začína v spoločenskom diskurze uvažovat’ o niečom takom ako sú všeobecne alebo absolútne platné hodnoty a ciele. Takéto úvahy sú podla národníckeho myslitela len na krok od spoločenskej deštrukcie a spoločenských konfliktov. Nakoniec aj samotná spoločenská aktivita Lavrova je príkladom toho, že sám prepadáva démonovi, ktorého tak bravúrne diagnostikuje vo svojej tvorbe. Za tento aspekt svojej prehnanej aktivity sa Lavrov stáva predmetom kritiky, a to

spojenie, ktoré však Lavrov nijak podrobnejšie nekomentuje. Ani v iných nám prístupných prácach sme sa s týmto slovným spojením nestretli. Autor v danom momente nepoužíva ani kurzívu.

9 V súvislosti s vyššie uvedeným dávame do pozornosti štúdiu Dekonštrukcia tyranie a perspektíva slobody $v$ myslení Étienna de La Boétiho (Pružinec 2015, 17-44), v ktorej autor reflektuje neuvedomovanie si svojho otroctva a utajovanie svojej závislosti. 
tak vo svojej dobe, ako aj v súčasných interpretáciách. To je ale dalšia velká téma, ktorú nie je možné v tomto textovom priestore uchopit'.

Lavrov sa snaží pristupovat’ k človeku, ako sme to mali možnost’ vidiet’, predovšetkým z funkčnej stránky. Jeho pohlad na človeka podlieha záujmu prepojenia teórie a praxe v spoločnosti. Človek vystupuje v podobe primárneho východiskového bodu takýchto zmien. Lavrov smeruje $\mathrm{k}$ tomu, aby objasnil možnosti a nedostatky spojené s človekom v procese dosiahnutia spoločenských zmien. Len na ňom závisí úspech i neúspech akýchkolvek snáh o zmenu spoločnosti.

Vzhladom na tento rámec Lavrovových úvah by sme chceli našu pozornost̉ podrobnejšie venovat vnímaniu sveta človekom. To je d’alšia $\mathrm{z}$ rovín, $\mathrm{v}$ ktorej venuje Lavrov pozornost človeku a má bezprostredný súvis so zámerom spoločenských zmien. Tvorba Lavrova nás tak privádza k otázkam postavenia človeka voči svetu. Na stranách Historických listov, odvolávajúc sa na Hegela, Lavrov (2010a, 53) uvádza: „Človek sa stal opät stredobodom celého sveta, no nie pre svet tak ako existuje sám osebe, ale pre svet chápaný človekom, pokorený jeho myslením a usmernený $\mathrm{k}$ naplneniu jeho cielov“. Vo svojich úvahách na túto tému pokračuje hned’ na nasledujúcej strane doplňujúcim tvrdením: „Celý vonkajší svet je pre človeka len materiálom pre uspokojenie, strast', túžby, konania“ (Lavrov 2010a, 54). Na tento moment nadväzuje dalšie zásadné tvrdenie, ktoré nás posúva do roviny striktne subjektívneho prístupu k svetu: „Všetky predmety a nástroje skúmania patria subjektívnemu svetu. Rôzne ciele, ktoré sledovali indivíduá a ich skupiny v každej epoche sú subjektívne. Subjektívnym je aj svetonázor, z ktorého vychádzajú hodnotenia týchto cielov ich súčasníkmi. Subjektívnym je aj hodnotenie výberu dominantného, hlavného dobového svetonázoru, ktorý formuluje historik v snahe určit za pomoci všetkých ostatných svetonázorov progresívny vývoj v dejinách ludstva, určit progresívne a regresívne obdobia, príčiny a dôsledky týchto fáz procesu dejín a ukázat jeho súčasníkom možné a želatel’né pre dobu, v ktorej sa daný historik nachádza“ (Lavrov 2010a, 69-70). V danom kontexte je potrebné spomenút, že podla Lavrova je podoba subjektívnosti danej epochy, podoba subjektívnych cielov, plnohodnotným vedeckým faktom. Aj ked’ tu píše Lavrov o historikovi, poukazuje na tendenciu vlastnú širšiemu hodnoteniu toho všetkého, čo sa udialo v minulosti a môže mat dopad na formovanie dobových idealizácií. Lavrov zdôrazňuje, že určitú dejinnú dobu je potrebné skúmat’ v jej kontextoch, zásadná chyba spočíva $\mathrm{v}$ nazeraní na minulé, a hlavne v hodnotení minulosti z pozície apriórnych morálnych a svetonázorových súdov, ktoré panujú v súčasnosti historika-nazerajúceho človeka a ktoré on sám zdiela. Iste doba, v ktorej historik žije, naň vplýva, no problém nastáva, ked’ svoju dobu a seba považuje za ten jediný kánon exegézy dejín, referenčný rámec, ktorý si tieto rozdiely a určenia nechce uvedomit', resp. ich pripustit'. Referujeme prirodzene z pozície Lavrovovej doby, no nazdávame sa, že odkaz Lavrova k tejto problematike môže vystupovat' daleko za horizonty 2. pol. 19. stor. Lavrov to považuje za nenáležité, chybné a dokonca za nevedecké. Hladanie nejakého jasného kritéria pre interpretovanie celých dejín považuje za absolútny nezmysel a mrhanie intelektuálnym potenciálom každého, kto sa o to snaží alebo bude snažit. Avšak môžeme brat za isté neabsolútne kritérium to, že ide o stálu, dobou určenú menlivost', ktorá je spojená $\mathrm{s}$ transformáciami človeka a jeho cielov v dejinách. Teda to, čo je možné považovat za prítomné $\mathrm{v}$ celých dejinách, je práve to určenie kritériami danej doby a prítomnost takýchto kritérií v rôznej podobe $\mathrm{v}$ každom dejinnom období a priestore. Rovnako nepovažuje za náležité vidieț v dejinách cestu naplnenia nejakého jedného dominantného zjednocujúceho ideálu; a už vôbec nie vidiet' náš súčasný stav ako vrchol, vyplývajúci z dejinných transformácií, ktoré sa začali niekedy dávno. Uvedomuje si však, že k tomuto často inklinujeme, že na základe toho hovoríme o vrchole progresu práve vo svojej dobe. Takéto aktivity by nám mohli poslúžit ako dobrý príklad chybnej, deštruktívnej idealizácie.

Efektívnou prevenciou pred deštruktívnymi idealizáciami je kritika a kritické myslenie. Možnost̉ kriticky mysliet', ako sme to ukázali pri vstupe k vymedzeniu človeka, je vlastná človeku 
ako bytosti. Je tou z možností, daností, ktorá ale nie je všetkými osobami naplňaná. V kritike vidí jednu z možností, ktorou človek disponuje, a zároveň aj jediné prípustné riešenie, nástroj pre vyvarovanie sa chýb nivočiacich spoločenský život. Kritika, ktorá je vlastná človeku, sa objavuje v Lavrovových úvahách ako istý fakt, ktorý je badatelný v celých dejinách: „Spomedzi všetkých odpozorovaných návykov je v prípade každej civilizácie badatelný návyk kritickosti, ktorý iniciuje ludský element dejín, potrebu rozvoja a prácu myslenia so zretelom na túto potrebu“ (Lavrov 2010a, 128). Dovolíme si zdôraznit', že samotná kritika nie je spasením samotným. Kritické myslenie ešte nie je odstránením nedostatkov, je vel'kou možnostou, ktorej využitie ale nie je samozrejmé. Je to skôr niečo žiaduce, potrebné. Kritické myslenie ako možnost’ by nás mala zaväzovat’ k tomu, aby sme využívali svoj tvorivý potenciál.

Úvahy v danom kontexte nás v štúdiu myšlienok Lavrova privádzajú k zaujímavej kategórii, ktorá priamo súvisí s vymedzením človeka. Ide o kategóriu viery, ktorá sa nevztahuje na náboženské učenie. Ide o vieru v seba, svoje sily a hodnotu cielov, ktoré si človek dokáže stanovit'. Ide o vieru v človeka, ktorý sa dokáže mobilizovat’ a prekonávat nástrahy, aby dosiahol stanovené ciele. Svoje poňatie viery vysvetluje podrobnejšie nasledovným spôsobom: „Viera je psychická alebo vonkajšia aktivita, počas ktorej je prítomné vedomie, no absentuje kritika“ (Lavrov 2010a, 240) a v tomto duchu dopracúva isté vyjasnenie: „Povedat, že viera je protikladom kritiky je možné, ale len v ohraničenom význame. To, čo v človek verí, už nepodlieha kritike. Nijako to nevylučuje možnost' verit’ v niečo, čo bolo včera predmetom kritiky“ (Lavrov 2010a, 240). Uvedené myšlienky obohacujú naše poznávanie filozofického uvažovania o možnostiach a nástrojoch, ktoré sú $\mathrm{k}$ dispozícii človeku ako potenciálnemu režisérovi a realizátorovi spoločenských zmien.

Lavrov nielenže vymedzuje vztah viery a kritiky, no vidí aj možnosti vzájomného dopíňania sa, spoluprácu kritiky a viery. Vyjadruje to ako stav človeka na dvoch úrovniach myslenia, alebo lepšie povedané, na úrovni kritického myslenia, ktorým dospejeme nielen k presvedčeniu, ale $\mathrm{k}$ viere o tom, čo je potrebné vykonat. Práve štádium viery je východiskom pre reálne konanie, uskutočnenie toho, v čo veríme. Je to možné chápat ako prechod od letargie, z ktorej sa kritickým myslením iniciuje konanie. To je založené na kriticky vypracovanej viere ${ }^{10}$.

Dané uvažovanie však súvisí s d’alším problémom. Spočíva podla nášho názoru v tom, že aj táto viera môže mat rôzne predmety, a teda ide o pojem, ktorý môže mat rôzne obsahy. Viera nie je garanciou progresu ani progresom samotným, predstavuje len možné zásadné východisko, ktoré tvorí základ pre konanie, pre realizáciu progresu a je vytvorená z kritického prehodnocovania.

Práve moment realizácie je zásadným momentom pre vymedzenie kvalitatívneho rozdielu medzi človekom, resp. osobou a indivíduom.

Funkčný prístup pri opise človeka má svoje bezprostredné odzrkadlenie aj pri identifikácii rozdielu medzi človekom a indivíduom, ktoré je realizátorom zmien v určitom dejinnom období. Uvedený rozdiel by sa mohol kryštalizovat za pomoci nasledujúcej myšlienky autora: „Indivíduá sú aj tak len potenciálnymi vykonávatelmi progresu. Jeho skutočnými vykonávatelmi sa stávajú až v momente, ked’ sú schopní bojovat', ked’ sú schopní transformovat’ sa z bezvýznamných jedincov na kolektívnu silu, predstavitel'ku myslenia. Je len jedna cesta, ako to urobit a tú ukazuje nepochybný dôkaz dejín" (Lavrov 2010a, 149). Kryštalizácia tu spočíva v stupňujúcej sa komplikovanosti, ktorej podstatou je to, že ani indivíduum nie je garanciou spoločenskej zmeny. Stáva sa garanciou vtedy, ked’ svoje chápanie progresu začína reálne naplňat. Znamená to, že jeho konanie nie je nevyhnutná záležitost', čo môžeme chápat ako zásadný problém pre dosiahnutie vzájomnej

10 Lavrov v poradí pätnástom Historickom liste formuluje nasledujúcu myšlienku: „Kritika podgotovljaet dejatel'nost', vera vyzivajet dejstvije“ (Lavrov 2010a, 241). Dané tvrdenie pre nás predstavuje zásadný problém pri preklade, a preto sme sa ho rozhodli uviest práve v poznámke pod čiarou. Uvedenú myšlienku Lavrova by sme mohli volne preložit nasledovne: „Kritika pripravuje k aktivite, viera iniciuje konanie.“ 
súčinnosti medzi teóriou a spoločenskou praxou vedúcou k zmene. Možné riešenie by sa podla nášho názoru dalo vysvetlit nasledujúcim spôsobom. Človek predstavuje jedinú bytost', ktorá je schopná uskutočňovat’ spoločenské zmeny na základe ideálu progresu, lebo „každý kriticky mysliaci človek, ktorý sa snaží uskutočňovat svoje myšlienky v živote, môže byt’ realizátorom progresu“ (Lavrov 2010a, 118). Lavrov však v danom kontexte formuluje isté obmedzenie používania všeobecného kvantifikátora „každý“ vo vzţahu k človeku. Ide o ohraničenie morálnej povahy: „Všetky bytosti, ktoré v sebe ešte nerozvinuli alebo nemôžu rozvinút vedomie vlastnej dôstojnos$\mathrm{ti}^{11}$ a pocit povinnosti konat' $\mathrm{v}$ prospech tejto dôstojnosti, sú postavené mimo morálneho konania“ (Lavrov 2010b, 351). Morálna rovina má v chápaní Lavrova určujúce postavenie aj v inom kontexte, ktorý vymedzuje nasledovne: „Ak sme uznali v prípade všetkých ludí rovnakú možnost̉ rozvoja $\mathrm{v}$ indivíduu alebo $\mathrm{v}$ rade pokolení, ak v morálnom rozvoji vidíme ich hodnotu a svoju morálnu povinnost' vidíme $\mathrm{v}$ konaní človeka na základe presvedčenia, tak nevyhnutne pre seba získavame morálnu povinnost podporit dôstojnost' iných ludí v rovnakej miere ako vlastnú, t. j. povinnost’ pomáhat ich rozvoju tak energicky a bezvýhradne, ako sme povinní smerovat' k vlastnému rozvoju行“ (Lavrov 2010b, 359). Predstavuje sa nám tak zatial' len akýsi základ pre spoločenskú zmenu, ktorý nemusí byt nijak naplnený. Ani rovina povinnosti tu nie je garantom pre reálne uskutočnenie, aj ked' rozdiel medzi človekom a indivíduom spočíva práve v uvedomení si potreby progresu a dôstojnosti každého iného človeka, no ani to nie je ešte garanciou progresu alebo naplňaním progresu. Avšak vedomie je predstupeň k uskutočneniu progresu, ktorý nie je možné vylúčit. To by nám mohlo vysvetlit podivuhodnú pozíciu $\mathrm{k}$ indivíduu, ktoré ešte stále nebolo garanciou zmeny, realizácie toho, čo je určené ideálom progresu, no je zároveň kvalitatívne odlišné od človeka, osoby.

Je však potrebné mat’ vždy na zreteli, že uvedomenie si toho, čo je vzhladom na potreby určitého dejinného obdobia stanovené ako progres, ešte neznamená progres ako taký, ktorý je hlavne realizovaním onoho presvedčenia o jeho možnosti. Ide však o kvalitatívny rozdiel v línii človek a indivíduum. Indivíduum sa stáva skutočným progresívnym činitelom až vtedy, ak progres naplňa: „Nevyhnutnost' zúčastňovat sa boja za progres predstavuje morálnu povinnost’ pre indivíduum, ktoré spoznalo význam tohto pojmu“ (Lavrov 2010a, 253). Ako nám to uvádza daná myšlienka, stáva sa to pre indivíduum povinnostou. Takýmto spôsobom sa utvára v dejinách indivíduum, ktoré Lavrov (2010a, 248) nazýva bojovníkom za progres: „Odkedy ludia prestávali verit' v nedotknutel'nost' spoločenského poriadku, ktorý im zanechali otcovia, od tej chvíle, ked' sa medzi nimi vypracovali osobnosti, ktorých myslenie sa už neobmedzovalo iba na dosiahnutie osobného záujmu pomocou existujúcich spoločenských foriem a podmienok, ale za ciel’ si vytýčili nájst’ a zrealizovat také formy spolužitia, v ktorých by sa celkovo žilo lepšie, - odvtedy sa vo svete neprestali objavovat bojovníci za progres“. Táto podoba indivíduí by splnila predstavu Lavrova priam v dokonalej miere.

V našej práci sme používali pomenovania neuralgického bodu a Achillovej päty. K druhému z motívov by sme sa na tomto mieste práce ešte vrátili. Úvahy o človeku v premene ruského spoločenského a politického života sú u Lavrova plné uvedomovania si úskalí. Okrem (ne) činnosti človeka a (ako) indivídua je problémom v ruskom kontexte aj absencia skupiny či priam množstva bojovníkov za progres. Lavrov takúto absenciu, rozmer Achillovej päty, citlivo reflektuje.

Tým by sme chceli uzavriet približenie tohto problému, formulujúceho sa na ceste ruských spoločenských zmien. Tie reálne nastali. Ak máme záujem pochopit zdroje formovania revolúcie v Rusku, nemali by sme zanedbávat poznanie národníckeho myslenia. Nemali by sme sa uspokojit’ s paušalizujúcimi tendenciami výkladu takými, ako táto z pera Struveho $(1990,135)$, podla ktorého

11 Rus. dostoinstvo. Dalo by sa to preložit aj ako hodnota.

12 Rus. razvitie. V textoch Lavrova sa zvykne nachádzat aj vo význame progresu. 
OSOBA, ČLOVEK A (AKo) INDIVÍDUUM VO FILOZOFICKOM UČENí P. L. LAVROVA. (KRITICKÉ POZNÁMKY K BYZANTSKEJ A SLOVANSKEJ DUCHOVNOSTI)

je národníckej inteligencii vlastný len „... protištátny charakter, ale aj jej bezbožnost“. Ide o tradíciu, ktorá hĺbkou svojich myšlienok určite nedosahuje úroveň Solovjovova či Dostojevského, no svojimi pozíciami formovala ruské myslenie v zásadnej a nespochybnitelnej miere.

\section{REFERENCES}

\section{Primary sources}

Lavrov, Petr Lavrovich. 2010a. Исторические писма [Historical Letters]. In Lavrov, Petr Lavrovich. Избранные труды. [The Collected Works] Moscow , 41-296.

Lavrov, Petr Lavrovich. 2010b. Социальная революция и задачи нравственности [Social Revolution and The Role Of Morality]. In Lavrov, Petr Lavrovich. Избранные труды. [The Collected Works]. Moscow, 345-451.

Lavrov, Petr Lavrovich. 2010c. Старые вопросы [Old Issues]. In Lavrov, Petr Lavrovich. Избранные труды [The Collected Works]. Moscow , 453-517.

\section{Secondary sources}

Arslanov, Rafael Amirovich. 2010. Петр Лаврович Лавров [Petr Lavrovich Lavrov]. In Lavrov, Petr Lavrovich. Избранные труды [The Collected Works]. Moscow, 5-37.

Bohun, Michat. 2008. Oczysyscenie przez burze. Kraków.

Broda, Marian. 2003. Narodnickie ambiwalencje. Międzi apoteozą ludu a terorem. Łodź.

Camus, Albert. 2004. Vzbúrený človek. Bratislava.

Grečo, Peter. 2014. Revolúcia, demokracia a masová kultúra. Poprad.

Malmenvall, Simon. 2015. Iskanje edinosti in vesoljnosti Cerkve : ekleziologija Vladimirja Solovjova in Georgija Florovskega. In Bogoslovni vestnik 75/2, 347-360.

Malmenvall, Simon. 2017. V iskanju idejnih predpogojev za uspeh boljševiške oktobrske revolucije. In Bogoslovni vestnik 77/3-4, 671-686.

Nizhnikov, Sergej Anatolievich. 2009. Духовное познание в философии Востока и Запада [Spiritual Cognition In Philosophy Of East And West]. Moscow.

Pomper, Philip. 1993. The Russian revolutionary intelligentsia. Wheeling.

Pružinec, Tomáš. 2015. Dekonštrukcia tyranie a perspektíva slobody v myslení Étienna de La Boétiho. In Manda, Vladimír - Stahel, Richard - Pružinec, Tomáš. Človek, sloboda a vlastníctvo vo filozofii raného novoveku. Bratislava, 17-44.

Pružinec, Tomáš - Gallo, Ján. 2016. Русская и персоналистическая философия в словацкой академической среде [Russian Philosophy and Personalism in Slovak Academic Environment]. In Vox. Философский журнал [Vox. The Journal Of Philosophy]. 10/21, 1-9. Rydzewski, Włodzimierz, 2014. Dylematy rosyjskiej idey. Kraków.

Struve, Petr Berngardovich. 1990. Интелигенция и революция [Intelligentsia and Revolution]. In Berdyaev, Nikolai Alexandrovich et al., (eds.) ВЕХИ. Сборник статей о русской интелигенции. [VEKHI. A Collection Of Articles Abouth The Russian Intelligentsia] Moscow, 131-149.

Walicki, Andrzej. 2005. Zarys Myśli Rosyjskiej od Oświecenia do Renesansu Religijno-Filozoficznego. Kraków.

Zverev, Vasilij Vasilevich. 2009. Русское народничество [The Russian Narodism]. Moscow. 
SUMMARY: PERSON, MAN AND (AS AN) INDIVIDUAL IN PHILOSOPHICAL TEACHINGS OF P. L. LAVROV. CRITICAL NOTES ON BYZANTINE AND SLAVIC SPIRITUALITY. The second half of the 19th century is known as the Russian intellectual and philosophical period as it is associated with new ideas and thoughts that have resonated throughout the centuries. In this period, Russian history does not experience its best times. Although the political situation of Russian history, accompanied by the Russian national movement of that time, is not the brightest, personalities, such as F. M. Dostoyevsky, V.S. Solovyov are coming on the scene in the hope of contributing to a change.

This study focuses on its main representative Petr Lavrovich Lavrov and his legacy in terms of a different view on a human being as an individual and a human (a person). According to Peter Lavrovich Lavrov, human being is the only extant species that can read, understand words and transform them into ideas/thoughts. Furthermore, only human beings can use their knowledge, gathered throughout their lives, and transform it into real action. The extent of that action presents the most important or favourable thing in people's lives and he (Lavrov) puts a lot of stress on practice. As previously mentioned, human being is again the only being that is able and capable of understanding the political situation and can transform or use this knowledge to make changes, bring new ideas and create a better society. Lavrov's point of views can be seen as a critical reflection of values created by Greek, Byzantine and Slavic spirituality. Faith is not accepted as faith in God. It is regarded as a strong belief which can lead to political action. It is a belief in goals created by man. This represents the fundament for the creation of a better world. The study also focuses on the difference between having a chance to change something and really changing something. This comes from a different perception of human being, where Lavrov views it as an individual, and a being (a human). Another skill of human beings is their capability to understand and comprehend bad conditions of their culture or life and make some changes. These changes come in place when the human being understands that he/she is an individual with such skills and power. This more than interesting study provides a further rumination on human beings, their place in the second half of the 19th century Russia and their power to contribute to a change.

Mgr. Ondrej Marchevsky, PhD.

University of Presov

Faculty of Arts

Intitute of Political Sciences

Department of Civic Education

17. novembra 1

08001 Prešov

Slovakia

ondrej.marchevsky@unipo.sk 